\title{
Filosofia e saúde: métodos genealógico e filosófico-conceitual
}

\author{
Philosophy and health: genealogical \\ and philosophical-conceptual methods
}

\author{
1 Núcleo de Estudos de Saúde \\ Coletiva, Universidade \\ Federal do Rio de Janeiro, \\ Rio de Janeiro, Brasil. \\ Correspondência \\ A. Martins \\ Núcleo de Estudos de Saúde \\ Coletiva, Universidade \\ Federal do Rio de Janeiro. \\ Rua Gustavo Sampaio \\ 520/1003, Rio de Janeiro, RJ \\ 22010-010, Brasil. \\ andremar@nesc.ufrj.br
}

\section{Abstract}

After a brief review of the relations between philosophy and health, this paper proposes two complementary philosophical methods to be used by Public Health: the philosophical genealogy method and the philosophical-conceptual method. The first method (deconstructive) allows us to denaturalize ideas to which a truth value has customarily been ascribed. The second (constructive) promotes new concepts whose value does not depend on the notion of truth. Both serve the purpose of reflection on concepts used by health policy and practice.

Philosophy; Social Sciences; Methods

\section{Introdução}

A filosofia vem participando das reflexões no âmbito da Saúde Coletiva no Brasil, desde o seu início - seja por intermédio de estudos de filósofos específicos que tematizaram questões da saúde, como Canguilhem e Foucault 1, seja na utilização da reflexão de cunho filosófico como apoio para que se pensem as questões da área 2,3,4,5,6,7,8,9, seja como base filosófica de correntes teóricas gerais da área tais como o positivismo, o materialismo histórico, a dialética, o estruturalismo, a fenomenologia. Contudo, é fato que a Filosofia não conquistou na Saúde Coletiva o reconhecimento que as Ciências Sociais, e mesmo as Ciências Políticas, conquistaram e consolidaram ao longo dos anos. Se é verdade que a filosofia já tem dado uma contribuição importante para as reflexões do campo da Saúde Coletiva, acreditamos que este pode se enriquecer ainda mais com ela, de modo fundamental nestes tempos de complexidade, transdisciplinaridade e novos paradigmas.

No intuito de propiciar a um número maior de profissionais e pesquisadores da área uma compreensão mais clara e ampla do papel possível da filosofia na Saúde Coletiva, pretendese, neste trabalho, propor duas metodologias filosóficas complementares, a do uso dos conceitos e a da genealogia filosófica, buscando operacionalizar seu uso para a área da Saúde e, em particular, da Saúde Coletiva. 
Desde que a área da Saúde Coletiva fora fundada no Brasil, conjugando a Saúde Pública, a Medicina Social e as Ciências Sociais em Saúde, a Filosofia tem tido papel fundante no que diz respeito a suas teorias. Assim, o positivismo, a dialética, o materialismo histórico, o estruturalismo e a fenomenologia são, todos estes, correntes sistemáticas do pensamento filosófico, e constituíram doutrinas e métodos na área da Saúde e em especial na da Saúde Coletiva. Constituíram-se, no entanto, como ideologias, isto é, seus métodos encerravam as pesquisas que a eles aderiam em uma visão de mundo preconcebida teoricamente. A filosofia tem sido, na área da Saúde, uma forma de definir correntes, caminhos em que, uma vez dentro deles, o pesquisador estará optando por um sistema, ainda que relativo, a partir do qual pensar suas questões, separando desde o início teoria e prática, inteligível e sensível. Uma vez dentro destes caminhos, a filosofia é esquecida enquanto fonte contínua de questionamento, desconstrução e reconstrução. Queremos propor, ao contrário, um método propriamente filosófico, de um uso constante intrinsecamente investigativo e questionador.

\section{Filosofia e saúde}

A relação entre Filosofia e Saúde está no interior da própria filosofia. Em toda a história da filosofia, esta foi vista como medicina da alma. A medicina cuidaria do corpo, enquanto a filosofia cuidaria da alma; algo como hoje se concebe usualmente a relação entre medicina e psicanálise. Na história da filosofia, tal concepção da filosofia como uma terapêutica, no entanto, torna-se mais forte com as filosofias que não dissociam corpo e alma. Por exemplo, e explicitamente, com Espinosa e Nietzsche. São filosofias que enfatizam a importância do ambiente e do afeto para o pensamento; ou mais precisamente, nos termos de Espinosa, são filosofias que entendem que nossas afecções, isto é, as impressões que os outros corpos e idéias nos fazem, geram em nós afetos, sentimentos, que influem em nosso modo de ver o mundo, estar no mundo, nos relacionarmos, pensarmos, conhecermos, valorarmos as coisas.

Uma filosofia terapêutica favoreceria portanto um conhecimento intuitivo, ou uma abertura para nossos afetos, muitas vezes inconscientes, o que nos permite entendermos melhor como nossos sentimentos funcionam. $\mathrm{Pa}-$ ra Espinosa 10, a terapêutica consiste basicamente em (i) estarmos aptos a perceber como se dá nosso funcionamento afetivo; (ii) selecionarmos nossos encontros (com pessoas, coisas, eventos, alimentos etc.) favorecendo aqueles que nos trazem afetos ativos; (iii) no caso dos maus encontros, pois em algum grau são sempre inevitáveis, posto que não podemos nem faz sentido desejar controlar o mundo em torno, trata-se de transformar os afetos passivos sentidos em afetos ativos. Algo como tornar-se, pouco a pouco, capaz de, como sugere Nietzsche 11 em sua teoria da grande saúde, fazer valer sua máxima o que não me mata me fortalece, usando como material de crescimento, enriquecimento e fortalecimento as vicissitudes encontradas. Selecionar os encontros diz respeito a contribuir ativamente para nossa forma de vida, buscando construir um ambiente físico e psíquico que nos favoreça o crescimento e a realização interna.

Estes filósofos desconstroem ilusões e acrescentam a isso uma filosofia afirmativa dos afetos. O que há em comum e está sempre em questão é a idéia de que nossos pensamentos influenciam nosso humor, nosso corpo, nossa vida, e, portanto, nossa saúde, seja individualmente, seja no âmbito do saber. Nossa saúde e a saúde como campo de saber só têm a ganhar abrindo-se à prática reflexiva, investigativa e questionadora da filosofia. Esta, por sua vez, ganha em concretude e em vigor, ao entender que a filosofia concerne a uma realidade presente e viva, e não a abstrações distantes da vida sensível. Trata-se de uma relação que vai no sentido contrário da idéia ainda familiar de que a filosofia não serve para nada. Serve, sim, inclusive para contribuir para nos tornarmos mais saudáveis.

\section{A intuição genealógica}

Espinosa 10 (p. 117) inaugurava a intuição genealógica quando, no apêndice à parte I de sua Ética, escrevia: "os homens são conscientes de suas volições e seus apetites, mas não pensam nas causas que os dispõem a desejar e a querer, porque as ignoram". Assim, explicava, os homens agem em vista de um fim, e acham que esta "causa final" é a causa das coisas, ou seja, que as coisas existem porque lhes servem para algum fim, e que os motivos de suas ações são os fins almejados. Porém, assevera Espinosa 10 (p. 117), “a natureza não comporta nenhum fim que lhe teria sido pré-fixado, e todas as causas 
finais nada mais são que ficções humanas". Em suma, "esta doutrina finalista inverte inteiramente a natureza, pois que considera como efeito o que na realidade é causa, e ao contrário, o que é anterior por natureza ela considera posterior" 10 (p. 119).

A genealogia está presente também em seu Tratado Político 12 (p. 307), quando analisa: "os filósofos concebem as emoções que combatem entre si em nós como vícios nos quais os homens caem por erro próprio. É por isso que se habituaram a ridicularizá-las, deplorá-las, reproválas, ou, quando querem parecer mais morais, detestá-las. Julgam assim agir divinamente e elevar-se ao pedestal da sabedoria, prodigalizando toda sorte de louvores a uma natureza humana que não existe em parte alguma, e atacando através de seus discursos a que realmente existe. Concebem os homens, com efeito, não tais como são, mas como eles próprios gostariam que fossem. Daí, por conseqüencia, que a maioria deles, em vez de uma ética, tenha escrito uma sátira". Espinosa foi o primeiro genealogista, no sentido nietzschiano do termo. Este sentido tem dois aspectos, que estão vinculados, seja qual for a ênfase dada a um ou a outro. O primeiro destes aspectos é o da genealogia como investigação das causas; o segundo, o de estas causas serem fundamentalmente afetivas.

A genealogia implica a investigação de causas em um sentido não cartesiano, a saber, sem linearidade, reducionismo ou mecanicismo, como também sem positivismo - características que estão interligadas. A linearidade das causas só é possível se reduzimos os complexos, vários e variáveis fatores causais a fatores simples, discretos, definíveis, delimitáveis, mecânicos. Assim fazendo, buscamos explicação na positividade de uma análise que, no entanto, para ser possível enrijece artificialmente fatores que na realidade não são assim rígidos. Na medicina dita biológica, isso é muito comum: a causa da pressão é o colesterol e o sal, a da diverticulite é a falta de fibras, e assim por diante. Como se para cada incômodo, dor ou disfunção correspondesse um sintoma e para cada sintoma correspondesse uma entidade nosológica, e para cada categoria diagnóstica uma carência e portanto um medicamento. O corpo humano é assim dividido em partes e tido como a soma simples destas partes, que se encaixam em um funcionamento mecânico, sendo visto, neste modelo, como uma máquina. Nesta concepção de causalidade, busca-se uma suposta única causa, que estaria na origem de uma cadeia de efeitos; esta única causa fora buscada nos átomos, depois nos quanta, e agora é buscada nos genes, renovando-se a ilusão de que um mapea- mento positivo de elementos substanciais, e por conseguinte um controle total da natureza, será um dia possível e o ser humano não terá mais a incerteza da vida a angustiá-lo.

A genealogia não busca a causa nesta acepção do termo. Ou melhor, não considera que se está, desta forma, conhecendo as causas de um certo efeito - mas sim que não se está chegando às causas, mas se encontrando explicações consoladoras por questões afetivas. Logo, estas causas são, em última instância, afetivas. É se investigando e se conhecendo os afetos que nos movem que poderemos atentar para as construções que fazemos nas mais diversas áreas como formas de defesa diante de nossas inseguranças e desejos. Mais, as causas apresentadas pelo racionalismo tradicional são antes ficções erguidas para ocultar inseguranças diante da complexidade e instabilidade do real. São abstrações imaginárias criadas com base na suposição de divisão do real em duas substâncias; nos termos de Descartes, a res extensa e a res cogitans, sendo o conhecimento considerado racional neste sentido aquele operado pela res cogitans que, como sujeito, observa a res extensa, seu objeto. Em Platão, a idéia é a causa do sensível, no sentido de que é o modelo das coisas materiais, que seriam suas cópias. Em Kant, o inteligível transcendental é um $a$ priori que põe nas coisas, no diverso sensível, o que delas pode conhecer. No modelo ontológico de separação entre mundo sensível e mundo inteligível, este aparece como causa daquele, como defesa onipotente, como uma tentativa imaginária de se dominar o mundo cuja incerteza e mutabilidade são sentidos como fonte de insegurança.

Quando Espinosa discorda de Descartes e alerta para o fato de que podemos falar de res cogitans e res extensa somente como dois aspectos, ou atributos, de uma única res, um único real, um único mundo, força a teoria a não mais manter-se como uma contemplação do intelecto sobre algo fora de si, mas como um conhecimento estético-sensório, intuitivo, propondo uma razão inserida no mundo e tendo o real não só como fonte mas também como fiel e fim de qualquer conhecimento que não se queira meramente imaginário, tal como todo e qualquer conhecimento ou razão concebida como separada do corpo. A partir de nossa unidade somatopsíquica, conhecemos inseridos no mundo, de modo que os motores de nossas ações serão sempre afetivos, resultado de nossa interação com o ambiente. A genealogia consiste, assim, neste sentido nietzschiano, de origem espinosiana, a investigar por detrás das obras, dos feitos, das ações e construções, o 
afeto e o valor que os motiva e rege. Nietzsche se sentira muito próximo de Espinosa quando conhecera sua filosofia, considerando-o seu único precursor. Nietzsche sofrera influência direta, no entanto, de Schopenhauer, embora deste discordasse em pontos fundamentais. Um dos pontos em comum entre os dois, todavia, é sem dúvida a intuição genealógica de Schopenhauer, que em seu Da Quádrupla Raiz do Princípio de Razão Suficiente denuncia as quimeras de uma razão que acredita encontrar causas onde apenas existem relações físicas, lógicas e formais, e ignora as motivações emocionais e a fonte de movimento e mudança da natureza - que Schopenhauer chamará de Querer ou Vontade universal. Schopenhauer (1843, apud Rosset 13) observou a primazia do querer sobre o intelecto: "em nossa própria consciência, a vontade se apresenta sempre como o elemento primário e fundamental, sua predominância sobre o intelecto é incontestável, este é absolutamente secundário, subordinado, condicionado" (p. 63).

Querer ou Vontade (Wille no original em alemão) que Freud 14, outro genealogista - apontado como tal por Foucault 15 juntamente com Marx -, confessará ser o que chamará de pulsão (Trieb), como força originária e irracional que move todas as coisas e o próprio ser humano. Em A Interpretação dos Sonhos, mais importa a intuição genealógica de que por detrás das razões formais há motivações psico-afetivas - que se expressariam nos sonhos. À razão cabe não ignorar esta fonte pulsional ou afetiva imanente, mas conhecê-la sem reduzi-la, construindo modelos ou exemplos de compreensão inseridos no mundo e atualizáveis a cada nova leitura ou utilização.

\section{Os métodos genealógico e filosófico-conceitual}

É com Nietzsche que a genealogia torna-se um método investigativo, que consiste basicamente em remontar às causas afetivas das ações, valores e argumentos aparentemente racionais presentes. Perceber o que está em jogo por detrás de explicações que não levam em conta o sensível e suas interações narcísicas, egoístas, emocionais. Nietzsche empregara tal método para desconstruir a crença na Moral 16 e na verdade, que até então não eram consideradas crenças, mas verdades transcendentes que se impunham ao mundo sensível como superiores a este. A moral e a verdade são sempre formas de ocultar egoísmo, culpa, disputa, política, e a origem destas construções defensivas é sempre a mesma: formas de depreciar a vida em nome de valores que a transcendam. Se até a modernidade a vida era depreciada em nome de um além, com a ideologia da ciência moderna a vida continua a ser depreciada, em nome de uma mesma vontade de verdade que diz algo como "a vida não se basta a si mesma, é preciso encontrar sua verdade para só então, por esta, ela valer a pena". A idéia de causalidade cartesiana encaixa-se perfeitamente nesta vontade de verdade; em nosso exemplo atual, o gene é a verdade que explicará os efeitos fenomênicos atuais.

A genealogia em Nietzsche é um método de desconstrução de valores, e da verdade em geral. Mostra-nos que valores são sempre ficções, criações, cabendo assim perguntarmo-nos em nome de que estes são erguidos. O fiel da balança proposto por Nietzsche é a própria vida: estamos criando regras e jogos, valorando as coisas, em prol de uma vitalização da existência; em prol, em termos espinosianos, de um aumento da potência de agir, de pensar e de viver? Ou por uma depreciação da existência tal como ela é, de forma reativa e defensiva?

Vemos que a genealogia é um método intrinsecamente ligado a uma medicina da alma, no sentido de diagnosticar genealogicamente sintomas de niilismo, de dificuldades de lidar com o trágico próprio à vida e de aprová-la em seus prazeres-e-dores, posto que estão intricados, "amorosamente enlaçados". Assim, Nietzsche propõe uma grande saúde, que seria a capacidade de amar a efetividade até mesmo em nossos momentos de enfermidade. Pela genealogia, ao invés de buscar-se uma verdade do já dado, a reconstrução de fatos, busca-se interpretar afetos genealogicamente presentes na origem de modos de vida e formas da cultura. Estes não seriam fatos, mas sintomas e índices de modos de encarar a vida e de inserir-se afetivamente no mundo.

Foucault, por sua vez, apreendeu da genealogia nietzschiana um correlato dos afetos, as forças, a vontade de potência, a luta de poderes. De Nietzsche, reapropria-se da idéia de que a genealogia não é uma história, não trabalha com dados ou com objetos como se fossem dados, não avalia o passado, não busca a origem. Afinal, escreve Foucault 17 (p. 17), "procurar uma tal origem é tentar reencontrar o que era imediatamente, o 'aquilo mesmo' de uma imagem exatamente adequada a si; é tomar por acidental todas as peripécias que puderam ter acontecido, todas as astúcias, todos os disfarces; é querer tirar todas as máscaras para desvelar enfim uma identidade primeira". A origem corresponderia a uma essência no início da histó- 
ria do objeto. O que Foucault quer mostrar é que não existe esta essência, justamente pelo fato de que é a própria história em seu caráter fortuito e acidental que forma objetos, que os objetiva. Tendemos a acreditar que os objetos nos são dados, sem perceber que encontros fortuitos criaram estes objetos, e que a permanência destes objetos acaba por nos dar a impressão que são objetos necessários, absolutos, dados, que têm uma essência transcendente ou ideal, que são substâncias em si mesmos, ou uma natureza, aparentemente necessária, biológica, que independem de relações e investimentos. $\mathrm{O}$ papel da história para o genealogista é o de permitir a desconstrução destas ficções de verdades, de propiciar colocar a nu a construção do que hoje aparece como natural e inevitável. "Ora, se o genealogista tem o cuidado de escutar a história em vez de acreditar na metafísica, o que é que ele aprende? Que atrás das coisas há 'algo inteiramente diferente': não seu segredo essencial e sem data, mas o segredo que elas são sem essência, ou que sua 'essência' foi construída peça por peça a partir de figuras que lhe eram estranhas", escreve Foucault 17 (p. 17-8), fazendo em seguida referências a diversos trechos de Nietzsche. Por detrás das coisas, em que pareceria haver uma essência ou uma etiologia mecânica ou orgânica, há na realidade acaso, lutas de poder, relações micro e macro políticas, paixão e ódio etc. O que hoje nos parece cristalizado e presente desde toda a eternidade tem, no entanto, uma história, a história de uma construção, que forjara objetos, crenças, identidades, modelos culturais, racionalidades, concepções do que sejam as coisas - a razão, a ciência, a liberdade, a moral, o comportamento correto para si e para os outros, o Bem, o Mal-, modos de valorar e de viver. "O genealogista precisa da história para conjurar a quimera da origem" 17 (p. 19). Sob o crivo genealógico, a ciência, o poder, o Estado, o sujeito, a moral são desconstruídos, desvelando saberes, poderes, epistemes, corpos, formas de subjetivação, enfim, redes de micro-relações, de efeitos pontuais e locais que transformam, sem seguir lei alguma, a história social e influem direta ou indiretamente na história afetiva de cada um.

Antes de se valer propriamente da genealogia, Foucault 18 inaugurou uma arqueologia como método de investigação, que seria, por assim dizer, uma genealogia das condições de possibilidade de um certo discurso, de certas práticas empíricas e discursivas, saberes, teorias e crenças. Foucault chamara este solo epistêmico que rege uma época determinada - isto é, um conjunto de formas de pensar e conce- ber as coisas, de modos de objetivação e subjetivação -, de episteme. A arqueologia que busca encontrar epistemes por detrás de práticas sociais e teóricas insere-se no procedimento genealógico, uma vez que participa da desconstrução dos objetos tidos por naturais, datando as objetivações ao inseri-las no quadro geral de uma época, de um campo de visão possível, de uma determinada cultura, de um modo cultural de ver o mundo e nele estar. Somos e pensamos inseridos em nossa época, não como essências inteligíveis, absolutas e fora do tempo. As representações e práticas, de saúde, por exemplo, de hoje, tanto por parte dos profissionais de saúde, quanto de usuários dos serviços, ou da população em geral, de algum modo refletem a episteme contemporânea seja sob qual aspecto for - em uma teia de fatores econômicos, sociais, epistemológicos, subjetivos, sem nenhuma sobredeterminação possível de um aspecto sobre outro. Não se trata, portanto, de nenhum determinismo, mas do fato de não podermos ser, agir ou escrever fora dos suportes de nossa época, cultura ou modo de ser - ainda que tenhamos discursos e ações atemporais, extemporâneas ou intempestivas, que sobrevivam ao tempo permanecendo sempre atuais, isto é, sempre potentes e passíveis de atualização.

Esta genealogia de cunho arqueológico sobre práticas discursivas e sociais, ou sobre modos de pensar e conceber as coisas - de conceber o conhecimento, a ética, a política etc. - pode ser realizada também em busca de paradigmas que abranjam diversas epistemes, observando modelos ontológicos comuns por trás mesmo de revoluções em um nível arqueológico mais superficial. É o que fizera Nietzsche com sua história do platonismo; ou mesmo Heidegger com sua historicização da metafísica.

Assim como estas práticas e hábitos discursivos se inserem em seu tempo, constituindo epistemes, apresentam também um correlato afetivo, visto que, se surgiram e permanecem, é porque respondem a alguma necessidade ou defesa psíquica, seja real ou imaginária, mas que pode se afigurar como paralisante e estagnadora. Teríamos assim dois aspectos da genealogia, um "horizontal", histórico - não como retratos de uma época mas como a construção problemática de objetos ao longo do tempo -, e outro seu correlato "vertical", encontrando nos afetos, sentimentos e emoções, nas necessidades e nas defesas propriamente psíquicas no lidar com o fluxo da vida, a gênese de comportamentos e construções individuais e coletivas a cada momento.

Deleuze 19 (p. 178) retoma com suas palavras a intuição genealógica nietzschiana quan- 
do diz: "os signos reenviam aos modos de vida, às possibilidades de existência, são os sintomas de uma vida em jorro ou vazia". O mesmo se pode dizer a respeito da concepção do mundo segundo Wittgenstein 20 quanto às palavras: emergem de formas de vida. Para Wittgenstein, a linguagem se faz a partir de usos, que por sua vez expressam e constituem formas de vida; $\mathrm{e}$ mais uma vez podemos, ainda mais propriamente, dizer o mesmo dos conceitos: seu uso se faz a partir de formas de vida, ao mesmo tempo em que constitui formas de vida. Giacóia 21 (p. 10) sintetiza a idéia da genealogia nietzschiana como "essa direção fundamental do olhar, que vai do fenômeno consideradoum personagem cultural, um corpus doutrinário, uma instituição sócio-política, uma fé religiosa, enfim, um evento significativo em qualquer das esferas da cultura - às condições originárias de seu surgimento e modificação". O método genealógico em Nietzsche 11 (p. 60) implica, portanto, tal como este o concebera e praticara, investigar a "retroinfluência que vai da obra a seu autor, do ato ao agente, do ideal àquele que dele carece, de todo modo de pensar e valorar à necessidade que se encontra por detrás dele comandando".

Logo, a genealogia afigura-se como método de desconstrução de objetivações e hipostasias, capaz de desconstruir e relativizar as crenças atuais. Compreendendo a formação das verdades atuais ao longo da história - história da civilização, da ciência e da filosofia - contextualizamos o que de outra forma poderia se nos apresentar como verdades, sejam absolutas ou relativas. A ela se segue a criação e o uso dos conceitos, como unidades operacionais, como instrumentos de construção de novas compreensões. Conceitos são, assim concebidos, modos de não fixarmos objetivações, criações sociais; são formas de recriarmos o mundo social sem a crença de estarmos disputando verdades ou valores absolutos, que sejam ditos metafísicos ou "científicos".

Desde seus primeiros textos, Nietzsche 22 (p. 48) denuncia genealogicamente o que consideramos como verdade: “o que é verdade portanto? Um batalhão móvel de metáforas, metonímias, antropomorfismos, enfim, uma soma de relações humanas, que foram enfatizadas poética e retoricamente, transpostas, enfeitadas, e que, após longo uso, parecem a um povo sólidas, canônicas e obrigatórias: as verdades são ilusões, das quais se esqueceu que o são". Verdades são fetiches, "metáforas que se tornaram gastas e sem força sensível, moedas que perderam sua efígie e agora só entram em consideração como metal, não mais como moedas" (p.
48). Para Nietzsche o discurso verdadeiro não tem valor; o único valor real é a potência de vida, a aprovação da vida e sua transformação para potencializá-la. A vontade de verdade, como vimos, deprecia por si só a vida. É neste sentido que Nietzsche 23 (p. 12) concebe a filosofia não como objeto de erudição, mas sim como devendo ser utilizada para a saúde: "aquele que quiser justificá-la terá que mostrar a que fim os povos saudáveis utilizam e utilizaram a filosofia". Entre estes povos saudáveis estariam os gregos (p. 14): "como eles, nós deveríamos aprender (...) colocando o saber adquirido a serviço da vida, enquanto suporte, e não a serviço do conhecimento erudito". Foucault 24 (p. 13) retoma num certo sentido esta intuição quando afirma: "de que valeria a obstinação do saber se ele assegurasse apenas a aquisição dos conhecimentos e não, de certa maneira, e tanto quanto possível, o descaminho daquele que conhece?". "Mas o que é filosofar", pergunta-se 24 (p. 13), "se não consistir em (...) pensar diferentemente em vez de legitimar o que já se sabe?” É característica intrínseca da filosofia "explorar $o$ que pode ser mudado".

É esta a ligação que existe entre a genealogia e a criação de conceitos: aquela, ao mesmo tempo que desconstrói, abre para a construção de novos conceitos, seja porque nos reapropriamos de conceitos antigos atualizando-os, seja porque modelamos os nossos próprios. Atualizar um conceito como instrumento filosóficoconceitual para a nossa contemporaneidade instrumento que nos permita, no caso, pensar as questões da saúde, psicanalíticas, psicossomáticas e médicas - torna-se assim o passo seguinte a uma desconstrução genealógica. Criar conceitos, propor sentidos novos, serve pois para dar uma luz nova a debates nos quais as pessoas tenderiam a estar cristalizadas em suas posições por não verem outras alternativas. Algo como: considera-se hoje saúde, cura, cuidado, de uma certa forma e segundo uma certa valoração, mas isso se deve a uma história (que a genealogia denunciará); é possível considerá-los e valorá-los diferentemente (propondo-se novos conceitos e novos sentidos para cada um destes termos). "Os filósofos (...) não devem mais se contentar em aceitar os conceitos que lhes são dados, para apenas limpálos e fazê-los reluzir; é preciso que comecem a fabricá-los, criá-los, colocá-los, e persuadir os homens a recorrer a eles", afirma Nietzsche (1885, apud Deleuze \& Guattari 25, p. 13-4). Deleuze \& Guattari 25 se valeram deste texto póstumo de Nietzsche para a tese de seu livro $O$ Que é Filosofia?, segundo a qual a filosofia se caracteriza pela criação de conceitos. Concei- 
tos que são instrumentos para se pensar a vida, para vitalizá-la, pensando-se com eles questões atuais. Em uma entrevista ao Magazine Littéraire, Deleuze 19 (p. 186) afirma: "não há nenhuma razão para fazer filosofia como Platão a fez, não porque ultrapassamos Platão, mas, ao contrário, porque Platão não é ultrapassável e não há nenhum interesse em repetir o que ele fez para sempre", concluindo: ou fazemos história da filosofia estrito senso, ou usamos os conceitos dos filósofos para pensar problemas que não são mais os deles.

Esta vitalização e atualização propostas por Deleuze e autorizadas por Nietzsche, encontram igualmente eco na compreensão de Wittgenstein 20 acerca das palavras, em sua imagem de que a linguagem seria como uma caixa de ferramentas, das quais lançamos mão conforme aquilo que queremos comunicar e o que intencionamos inventar. O mesmo podemos dizer a respeito dos conceitos, como ferramentas ainda mais precisas que as palavras do uso comum. E mais, ao filósofo cabe criar suas próprias ferramentas conceituais, modulando, interpretando e recriando aquelas existentes, a fim de lançar mão delas de acordo com os problemas que precisam enfrentar, e para os quais, em sua concepção, as ferramentas existentes podem até servir, contanto que atualizadas e reinterpretadas.

A metodologia de criação filosófico-conceitual deve portanto ser utilizada para pensar problemas, da área da saúde por exemplo, que não foram os que os filósofos pensaram quando criaram suas filosofias e seus conceitos. Problemas contemporâneos, nossos, de agora, do tempo presente. Quanto à questão de quais conceitos utilizar, e para quais casos, a resposta é que os próprios problemas com os quais nos defrontamos hoje nos pedem problematizações e soluções para os quais pensaremos em conceitos da história da filosofia que nos servirão, caso atualizados - tomados pois como ferramentas, e não por uma erudição estéril -, ou que nos inspirarão modificações, de modo que construiremos com base naqueles os nossos próprios. Dispondo de caixas de ferramentas diversas, isto é, de filosofias diversas, devidamente contextualizadas, podemos compreender seus conceitos no lugar de origem, na filosofia que lhes gerara, e a partir dessa compreensão, retirar este conceito - já nuançado em seu sentido -, isolá-lo e utilizá-lo como ferramenta para redimensionar e repensar uma questão atual. Seja recriando conceitos, seja redefinindo conceitos já existentes, seja forjando novos conceitos, estes nos servirão para estabelecer matizes de sentido que esclarecerão confusões da prática e do debate atual em saúde.
Uma metodologia, portanto, filosófico-conceitual, consiste na criação e/ou utilização de conceitos que nos permitam propor modos de ver o mundo, ou um problema específico, que o vitalize, de uma maneira outra que a habitual, por mais que esta um dia possa ter sido questionadora ou inovadora, cuja cristalização fora denunciada pela genealogia. Pelo método genealógico podemos contextualizar inclusive nossa própria criação conceitual. Compreendida a função filosófica do conceito, podemos utilizá-los como um instrumento propositivo de novos modos de ver e estar no mundo, como ferramenta para pensarmos os tempos atuais assim como problemas de outras áreas do conhecimento e da vida social que não a filosofia, como por exemplo, a área da saúde, incluindo as várias áreas da Saúde Coletiva, como também a psicanálise, a psicossomática e a própria medicina.

Em síntese, cabe neste sentido à Filosofia: (i) perceber e analisar as "condições de possibilidade” paradigmáticas e epistêmicas tanto das diversas concepções do que seja saúde no decorrer do tempo, quanto das diversas práticas de saúde existentes no decorrer do tempo. Este trabalho filosófico seria propriamente um trabalho genealógico; (ii) perceber e analisar as "condições de possibilidade" de nossas práticas e concepções individuais do que seja saúde, em correlação com as concepções mais gerais de nossa cultura, sociedade, publicidade, mídia, grupo social etc. - seria um trabalho filosófico genealógico também, mais voltado para o indivíduo e seus afetos, seus mecanismos narcísicos e defensivos; (iii) percebendo desta maneira que os conceitos envolvidos na concepção do que seja saúde mudam com o tempo, variam de época, cultura e sociedade, de modo que não são verdadeiros em absoluto, mas construídos de acordo com crenças e interesses (hoje, segundo interesses da indústria farmacêutica e de equipamentos da biotecnologia, por exemplo), cabe conceber e elaborar novos conceitos, fundamentados em novos valores - por exemplo que levem em conta não os interesses do mercado mas sim, propriamente, a saúde das pessoas no sentido de sua capacidade ou potência de agir e de pensar, pensando o papel dos profissionais da saúde como o de buscar a reabilitação do paciente para sua existência e não somente para que dê lucro a algum investidor.

Ou seja, a filosofia tem: (a) um papel de desconstrução de crenças e naturalizações atuais, problemáticas para nossa contemporaneidade, desmascarando interesses reativos e mecanismos defensivos por detrás destes discursos que 
se propõem verdadeiros e hegemônicos; (b) um papel de construção de novos conceitos, valores e formas de conceber a saúde e a vida, abrindo a novos modos de nos afetarmos e nos inserirmos no mundo.

\section{À guisa de conclusão: aplicações}

É claro que as aplicações da metodologia que vimos exige a cada problema enfrentado um trabalho inteiro e à parte. À guisa de conclusão nos limitaremos a apontar para trabalhos já realizados, somente como ilustração de aplicações possíveis da metodologia proposta para a área da saúde.

No que diz respeito à genealogia aplicada a temas da saúde, o próprio Foucault realizou estudos genealógicos sobre os temas da clínica médica 26 , da medicina social, do hospital 17 , da psiquiatria e da doença mental 17,18. Além disso, seus estudos sobre as ciências humanas 27 , a sexualidade e a subjetividade 24 servem de subsídio para desconstruções e reflexões sobre aspectos importantes das práticas de saúde, no que o poder e o controle da singularidade se fazem valer por intermédio dos discursos e políticas do que seja e o que não seja saudável e/ou "cientificamente" saudável. Genealogias de inspiração foucaultiana na área da psiquiatria foram realizadas por Machado et al. 28 e por Portocarrero 29. Martins 30 realizou um esboço de genealogia da concepção de saúde e das práticas médicas atuais, em seguida propondo uma nova concepção de saúde. Carvalho 31 realizou um estudo sobre o conceito de obesidade, reconstruindo-o com base em uma crítica genealógica ao paradigma mecanicista, que retira a complexidade do metabolismo reduzindo-o a uma balança de aquisição e queima de calorias, tomando a nutrição pelo modelo de uma locomotiva em que a lenha se transforma em energia dentro de uma máquina que seria o corpo, como se os nutrientes não constituíssem o próprio corpo e sua capacidade de ter potência e desejo. Em particular na área psi, Martins 32 procurou descontruir certos conceitos freudianos tomados como naturais e necessários, tais como o de pulsão de morte, um típico caso de um efeito hipostasiado e considerado como causa. Buscou também desconstruir a concepção da psicose como estrutura distinta essencialmente da neurose 33 . Seguira nisso a desconstrução das entidades nosológicas psiquiátricas operada por Winnicott 34 ; assim como a tese de Armony 35, que por um lado desconstrói da idéia de uma fronteira efetiva entre neurose e psicose, e, por outro, constrói uma nova concepção conceitual segundo a qual somos todos de algum modo personalidades borderline, necessariamente com traços tanto neuróides quanto psicóides. No sentido de novos conceitos no que diz respeito à saúde, já Espinosa 10, no século XVII, propunha, como vimos, uma concepção de saúde ligada à potência de agir; e no século XIX, Nietzsche propunha o que chamara de a grande saúde. Neste mesmo sentido, Canguilhem 36,37 continua sendo o grande autor do século XX a fazer uma crítica à normalidade e à patologia, e a propor um novo conceito de saúde baseado na idéia de uma plasticidade e capacidade normativa singular, concebendo um vitalismo não animista.

Muitos são, enfim, os trabalhos genealógicos, e muitos os que criam conceitos sem fixálos em significações estanques ou sistemas fechados. Tentamos aqui apresentar estes procedimentos na forma de uma metodologia, a fim de favorecer sua operacionalização, tendo em vista a importância, a nosso ver, deste olhar crítico e desmistificador em uma área como a da saúde, tradicionalmente apegada ao cientificismo e à procura de leis últimas que pudessem supostamente corrigir ou curar a existência, seja esta pensada individual ou coletivamente. Não nos resta dúvida de que estes métodos, genealógico e conceitual, separadamente ou encadeados, podem trazer às reflexões no campo da saúde um caráter crítico e questionador próprio da filosofia naquilo que ela tem de não ideológica ou sistemática, mas de desconstrutora de crenças e cristalizações e construtora de suportes de vitalização, não de aplicação de teorias sobre a prática, mas de vitalização do próprio sensível no qual somos e agimos. 


\section{Resumo}

Este artigo, após uma contextualização teórica da interface filosofia e saúde, propõe dois métodos filosóficos complementares de aplicação para a área da Saúde Coletiva: o da genealogia filosófica e o filosófico-conceitual. O primeiro, desconstrutivo, permite a desnaturalização de idéias às quais se atribui um valor de verdade. O segundo, construtivo, promove reconceitualizações cujo valor não mais se oculta sob a idéia de verdade. Ambos não encerram doutrinas filosóficas e mantêm o caráter questionador da filosofia, constituindo-se como um instrumental para se pensar os conceitos envolvidos e propostos nas práticas e políticas de saúde.

Filosofia; Ciências Sociais; Métodos

\section{Referências}

1. Machado R. Ciência e saber: a trajetória da arqueologia de Foucault. Rio de Janeiro: Graal; 1981.

2. Luz M. Natural, racional, social. Rio de Janeiro: Campus; 1988.

3. Castiel LD. O buraco e o avestruz: a singularidade do adoecer humano. Campinas: Papirus; 1994.

4. Castiel LD. A medida do possível: saúde, risco e tecnobiociências. Rio de Janeiro: Editora Fiocruz; 1999.

5. Ayres JR. Epidemiologia e emancipação. São Paulo: Editora Hucitec/Rio de Janeiro: ABRASCO; 1995.

6. Ayres JR. Sobre o risco: para compreender a epidemiologia. São Paulo: Editora Hucitec; 1997.

7. Camargo Jr. KR. Biomedicina, saber e ciência: uma abordagem crítica. São Paulo: Editora Hucitec; 2003

8. Almeida Filho N. Epidemiologia sem números: introdução crítica à ciência epidemiológica. Rio de Janeiro: Campus/ABRASCO; 1989.

9. Almeida Filho N. A ciência da saúde. São Paulo: Editora Hucitec; 2000.

10. Espinosa B. Ética. Lisboa: Relógio d'Água; 1992.

11. Nietzsche F. Nietzsche contra Wagner. São Paulo: Cia. das Letras; 2000.

12. Espinosa B. Tratado político. São Paulo: Abril Cultural; 1983.

13. Rosset C. Schopenhauer. Paris: PUF; 1968.

14. Freud S. Uma dificuldade no caminho da psicanálise. Rio de Janeiro: Imago; 1987.

15. Foucault M. Nietzsche, Freud e Marx. São Paulo: Princípio; 1987.

16. Nietzsche F. Genealogia da moral. São Paulo: Cia das Letras; 1998.

17. Foucault M. Microfísica do poder. Rio de Janeiro: Graal; 1979.

18. Foucault M. Arqueologia do saber. Petrópolis Editora Vozes; 1972.

19. Deleuze G. Conversações. Rio de Janeiro: Editora $34 ; 1992$.

20. Wittgenstein L. Investigações filosóficas. Lisboa: Calouste Gulbekian; 1995.

21. Giacóia O. Nietzsche como psicólogo. São Leopoldo: Editora Unisinos; 2001

22. Nietzsche F. Verdade e mentira no sentido extramoral. São Paulo: Abril Cultural; 1983.
23. Nietzsche F. La philosophie à l'époque tragique des Grecs. Paris: Gallimard; 1990.

24. Foucault M. História da sexualidade. Rio de Janeiro: Graal; 1984.

25. Deleuze G, Guattari F. O que é Filosofia? São Paulo: Editora 34; 1992.

26. Foucault M. O nascimento da clínica. Rio de Janeiro: Forense Universitária; 1998.

27. Foucault M. História da loucura. São Paulo: Perspectiva; 1978.

28. Machado R. Danação da norma: medicina socia e a constituição da psiquiatria no Brasil. Rio de Janeiro: Graal; 1978.

29. Portocarrero V. Arquivos da loucura. Juliano Moreira e a descontinuidade histórica da psiquiatria. Rio de Janeiro: Editora Fiocruz; 2002.

30. Martins A. Novos paradigmas e saúde. Physis (Rio J) 1999; 9:113-21.

31. Carvalho MC. Reconstruindo o conceito de obesidade [Dissertação de Mestrado]. Rio de Janeiro: Núcleo de Estudos de Saúde Coletiva, Universidade Federal do Rio de Janeiro; 2003.

32. Martins A. Pulsão de morte? Natureza e cultura na metapsicologia freudiana [Tese de Doutorado]. Rio de Janeiro: Programa de Pós-graduação em Teoria Psicanalítica, Universidade Federal do Rio de Janeiro; 2002.

33. Martins A. Criação e psicose: repensando a metapsicologia das psicoses. In: Amarante P, organizador. Ensaios: subjetividade, saúde mental, sociedade. Rio de Janeiro: Editora Fiocruz; 2000. p. 75-94.

34. Winnicott DW. Existe uma contribuição psicanalítica à classificação psiquiátrica? $\mathrm{O}$ ambiente $\mathrm{e}$ os processos de maturação. Porto Alegre: ArtMed; 1983.

35. Armony N. Borderline: uma outra normalidade. Rio de Janeiro: Revinter; 1998.

36. Canguilhem G. O normal e o patológico. Rio de Janeiro: Forense Universitária; 2000.

37. Canguilhem G. La connaissance de la vie. Paris: J. Vrin; 1992.

Recebido em 27/Ago/2003

Aprovado em 12/Jan/2004 